\title{
Architectural Practice in the Context of Post-Criticality: Spatial Thinking from City and Behavior of Atelier Bow-Wow
}

\author{
JIANFEI YANG \\ Tongji University
}

\author{
CHEN QIAN \\ Tongji University
}

\begin{abstract}
The theory and architecture practice of Atelier Bow-Wow highlight social engagement and strive to extract spatial concepts from the context of Asian cities and human behavior. They discovered problems that disciplinary autonomy and formal manipulation cannot solve, and concluded spatial prototypes. The article reveals the urban and spatial research of Atelier Bow-Wow, and analyzes their 3 projects of which the spatial concepts all start with urban environment and human behavior, instead of morphology. The research and design projects can help us to think deeply on how architects can transcend form, and discover spatial possibilities outside architecture discipline.
\end{abstract}

\section{INTRODUCTION: THE THIRD PRACTICE MODE IN THE CONTEXT OF POST-CRITICALITY}

A famous theorist in post-critical area, Stan Allen, drew 3 diagrams on architectural design modes.

The first one is dumb practice, which is built as a resultant of professional codes and conventions. This type of practice accommodates contingency and forms a closed figure. It mechanically projects architectural design on the environment without consideration of aesthetics (fig.1-1). The second one is especially common in architectural area which pays more attention to autonomy. In this "dumb theory" diagram, building is seen as a subset of the codes and conventions of theory and tends to be "form-oriented", which turns inward to protect building from contingency (fig.1-2). Neither of the two modes can create impressive space nor face the complex society. They are particularly insufficient in multiplex Asian districts.

Unlike the historical European cities of centuries, the new cities in East Asia (including Tokyo and Shanghai) are the production of disorderly construction under the economic boom of the last century. In the process of historical development, European cities gradually formed a stable and consistent urban spatial rules and orderly urban fabric. Rossi's urban typology is based on this orderly form of the city as the basis for the development of a morphological type of architectural design. However, due to the crazy construction under the economic expansion, East Asian cities are characterized by chaos and disorder. In the chaotic city environment, the citizens still have the desire for free and personalized living space, which is the practice context that today's Japanese architects have to face.
Atelier Bow-Wow is an architectural studio from Tokyo, Japan. Their theory and practice corresponds to the third diagram: pragmatic realism. Atelier Bow-Wow see practice as the intersection of architecture's inside and it's outside (fig.1-3). On the one hand, they explore the inner logic under the chaos of Japanese cities from the perspective of theoretical studies to seek opportunities for space. On the other hand, they are continuously fed back by urban architectural practice to supplement or perfect their theoretical research. The two open parts overlap to form an indeterminate figure. Faced with complicated reality, they maintain the design ideas from education of modernism. Therefore their design projects have both design intelligence and design sense. It is an optimistic attempt towards architectural practice in the future. Form is no longer the dominant element in spatial organization. Atelier Bow-Wow derives more spatial concepts from city, behavior and other elements outside the architecture discipline.

\section{ARCHITECTURAL THEORY AND RESEARCH: SPATIAL CONCEPTS FROM THE CITY AND HUMAN BEHAVIOR}

Atelier Bow-Wow's Yoshiharu Tsukamoto and Momoyo Kaijima belong to the generation of architects that received no benefit from the Japanese economic bubble of the 1980s. In the 1990s, Japan experienced a recession as a result of an economic crash. This caused the number of new construction projects especially large-scale projects fall sharply. Consequently, many architects chose to devote themselves exclusively to designing houses during this period.

At that time, after experiencing economic expansion, Japanese cities were plunged into disorganized chaos and the fabric of the former cities were disappeared. There was neither the opportunity nor the desire to seek the morphological consistency between the new buildings and the old ones. On the other hand, under the system of private ownership of land, individual independent housing projects began to flourish. Due to the high inheritance tax in Japan, people have to sell the land for the purpose of building independent houses. Therefore, there are growing requirements for the quality and individuality of living space. In this context, Tsukamoto and Kaijima kept their eyes on the Asian cities and the human behavior research

From their perspective, the city was not something that should be subjected to a top-down, authoritarian approach to planning. Following cultural historian Michel de Certeau's distinction between "strategy" and "tactics", we can say that 


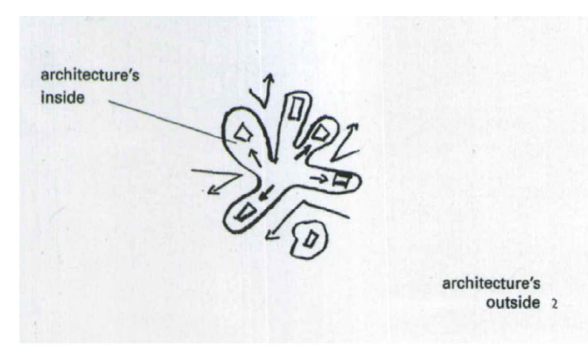

1-1: Dumb Practice

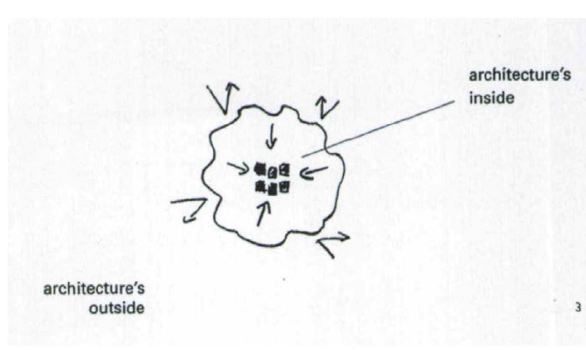

1-2: Dumb Theory

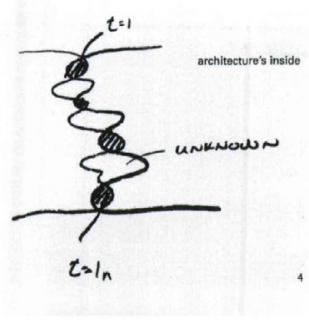

1-3: Pragmatic Realism

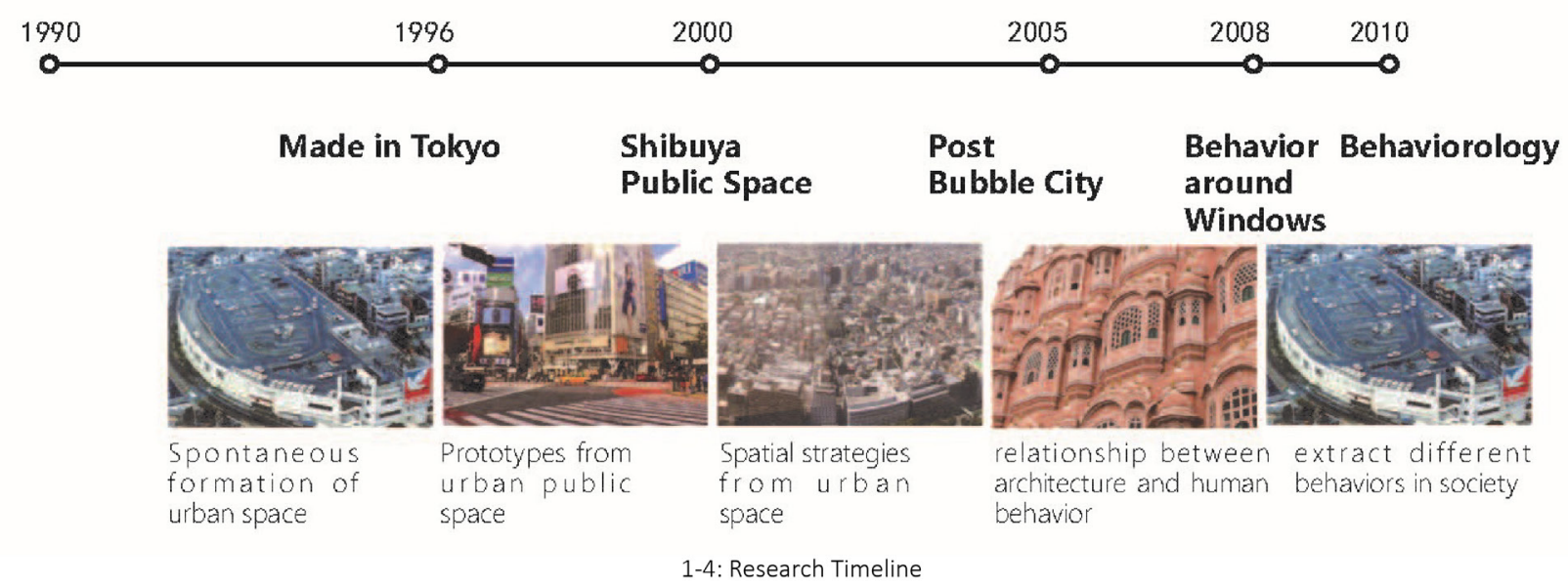

Fig.1: Stan Ellen's diagram and atelier Bow-wow's research

Atelier Bow-Wow started intervening in the existing urban space from the standpoint of "tactics", observing the spatial organization and extracting spatial concepts. The famous publications include "Made in Tokyo" and "Post Bubble City" which studied the functional mix behind the chaotic urban spaces and explored contemporary living space modes in Japanese cities. These theories continued to prove that the urban development of Tokyo, as one of the emerging cities in East Asia, is not a morphological growth based on urban fabric but rather a chaotic functional overlay and spatial dialogue.

Moreover, they published some researches and theories which focus on public space and human behavior, such as "Behaviorology", "Behavior around Windows" and "Shibuya Public Space". These publications discovered some spaces influenced by behavior from sociological perspective. Behaviorology turns subjectivity immediately, which helps us to rethink what is the dominant part after introducing distinct elements. This method expands traditional architectural design process in a brand perspective (fig.2). Through these theories, Atelier Bow-Wow is constantly exploring the possibility of living space types in contemporary society. At the same time, based on behavioral research, Atelier Bow-Wow are trying to establish the order of internal space to resist the chaotic urban environment.
The down-up perspective reveals the different view of Atelier Bow-Wow. After the success of "Made in Tokyo", Atelier BowWow achieved many housing projects. They got chances to apply the spatial concepts from their research. These space concepts have two common important arguments. One is that the attitude toward the urban environment in East Asia would not be based on urban fabric morphology but based on the positive dialogue between architecture and urban space. The other one is to emphasize the importance of spatial model from behavioral theory to dominate the interior of architecture and matches the lifestyle.

These two aspects of strategy are directly reflected in many of their architectural designs. In the following, three typical single-family homes will be used as a clue to further analyze Atelier Bow-Wow's spatial design approach based on the urban and behavioral research.

\section{ARCHITECTURAL PRACTICE WHICH MIXED URBAN INFLUENCE AND BEHAVIOR}

3.1 House and Atelier Bow-Wow

House and Atelier Bow-Wow is located in the densest part of Tokyo. The site is surrounded by buildings and only connected to the road by a narrow strip of land. The architects, Yoshiharu Tsukamoto and Momoyo Kaijima, designed this split-level house which connected the lower 2 floors for the atelier and 


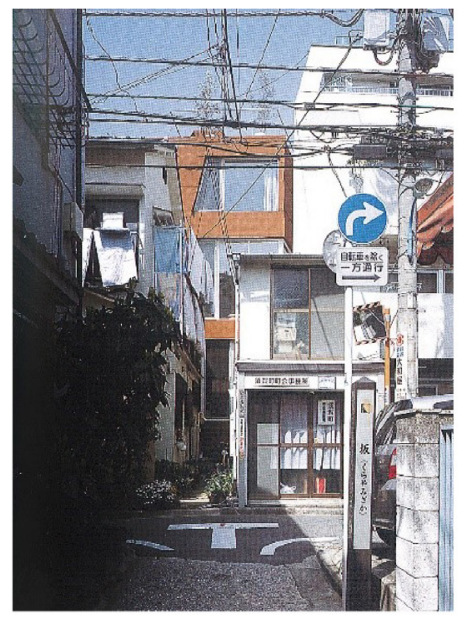

2-1: House and Atelier Bow-wow

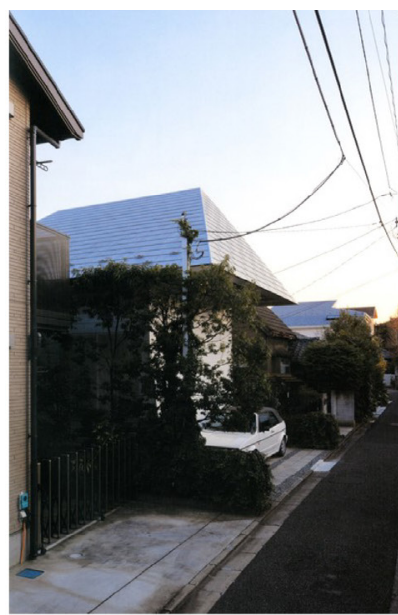

2-3: Gae House

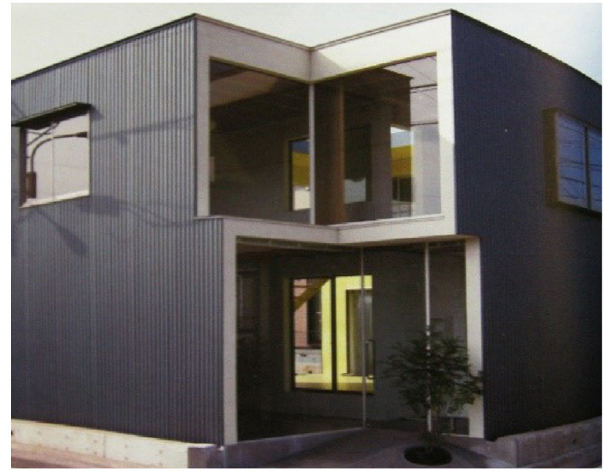

2-2: Loco House

Fig. 2 : Street view of three projects

upper 2 floors for the house with a staircase. The unusual large windows invite the urban environment into the public space in this building, which brings light and ventilation. In this project, the public space refers to the Atelier Bow-Wow, while the private space refers to the house itself. And the two distinct functions are combined.

In design of House and Atelier Bow-Wow, the building did not mold form by imitating the surrounding environment. To ensure the maximum capacity, the site is also used as a 3D space where a very direct shape linked the ground and sky together. Unlike the countryside, the open space between the building and the surrounding plots cannot be designed freely. Through the minimal number of artificial processing, architects achieve the maximum surface area. The large facade is erected in a high-density residential area which achieving a sense of distance from the surrounding faculties of the building façade and resulting in a "blank" state. This conceptual response to urban space directly shapes the form of architecture, rather than from the formal beauty point (fig.3-1).

As for the behavior, the architect conceived a shared circulation for two circulations. Except for the circulation towards basement level, which is not often used by the house owner, other public circulations are shared by the host and staff. The host goes home through the working area. The circulation arrangement spares space and avoids possible conflict by vertical separation of public character. The analysis of behavior of host and staff contribute to the limited space. And the spatial distribution also brought unexpected interior space and outside look. For example, the big window in the dense district. It is a living room as well as architecture studio, therefore the space is more public then usual residence (fig.3-2).

\subsection{Loco House}

Another project designed by Yoshiharu Tsukamoto and Momoyo Kaijima, Loco House, is also located in Tokyo. It is a house with a barbershop on a site of $79 \mathrm{~m} 2$ for 4 family members: a grown-up son, parents and a grandmother who are all barbers. The priority was to make the most use of the small area. The architects put a small courtyard at the center of the site to give the space a physical distance that is necessary for the co-existence of 3 generations, a house and a shop. The void in the building is called "sky room", with an opening of $2.5 \mathrm{~m} \times 2 \mathrm{~m}$ in the ceiling. A corner of the house was cut away, making the face of the shop and the "sky room" open up to the street. In this project, the public space refers to the barbershop, while the private space refers to the private house.

The site is at the corner of a residential area in countryside. Due to the limitation of the base area, the architect occupies the floor area as much as possible. At the same time, to avoid a congested view from the crossroads, the architects cut one of the corners of the rectangle volume, forming the shape of the house directly and creating an entrance to the internal courtyard. The subdivision of the land and the relationship of the city apace dominated the exterior of the house (fig.4-1).

From the point of behavior, the organization of space adapted to the external volume and indoor space requirements. The different generations in family live in the different rooms on two floors which need to maintain their independence in a limited area. At the same time, there is a family business barber shop near the entrance which is a relatively public space. These conflicts between public and private are defused through the setting of an indoor courtyard which makes the shop and the house can share a common courtyard as a second public space after the street. A simple square courtyard directly become a prototype of the internal space, allowing public and private acts to proceed at the same time (fig.4-2).

\subsection{Gae House}

The Gae house, at last, is located in residential district in Okusawa which is being challenged by land subdivision and an increase in car parking space. To solve these problems, architects made a $1.5 \mathrm{~m}$ wide space $(2 \mathrm{~m}$ at roadside for parking) around the house by putting up the largest possible roof defined by height and setback regulations. This 


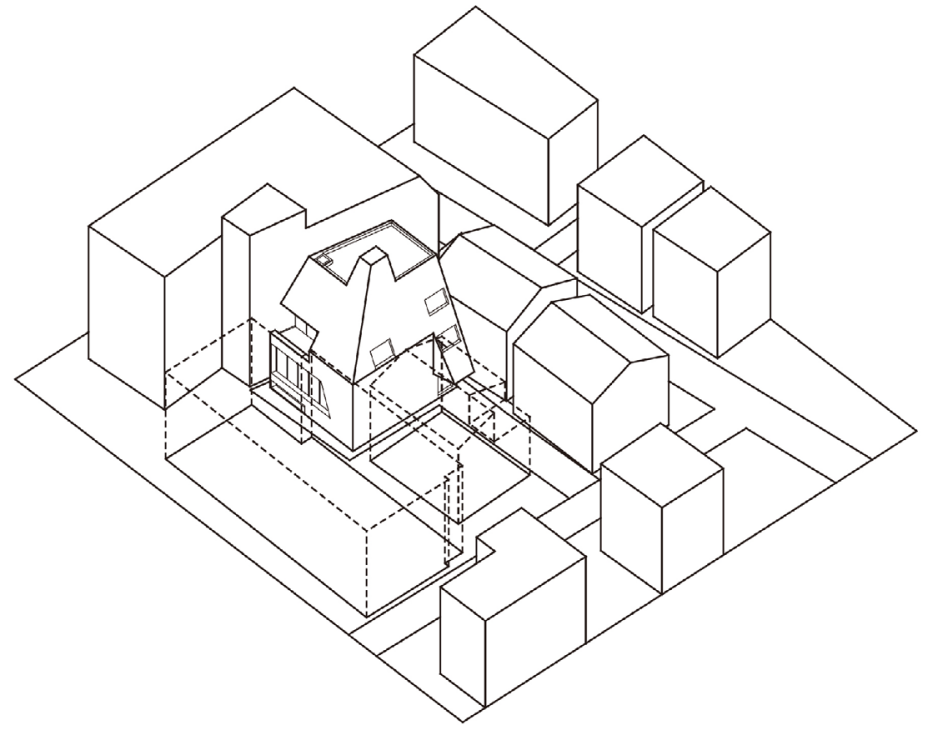

3-1: Site of House and Atelier Bow-wow

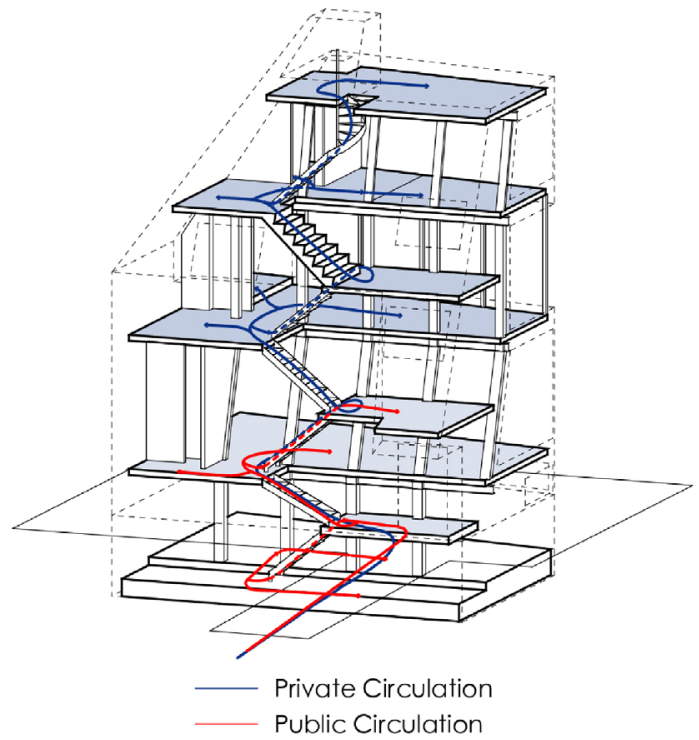

3-2: Mixed Circulation in House \& Atelier Bow-wow
Fig.3 : analysis of House and Atelier Bow-wow (drawn by the author)

disproportionately big roof, with "horizontal windows" made by setting glass between the edge of the roof and the wall, make good use of the gap with the next lots. The man at the second floor will have a good view at the parking area. For Gae house, the public space refers to the gap space and parking area, while the private space refers to the interior.

The house is situated in a subdivided land in Kanazawa. The new house need to keep the distance to the existing buildings as well as to set aside a parking space. To maximize the interior space, the architects set the perimeter of the ground floor close to the control line forming a gap space and a parking area around the house. At the same time, a largest roof is put up which is also defined by height and setback regulations. The form of the whole building comes entirely from the urban environment and the demand for maximizing the area rather than dominated by formal aesthetics or spatial effects (fig.5-1).

As for the behavior, the architects create "horizontal" windows by setting a continuous glass between the edge of the roof and the wall. This "horizontal" window reflects light onto the metal deck plate of ceiling defusing light into the second floor. View from inside through the "horizontal windows" varies depending on one's standing point, one can not know where the floor lines are from outside, thus a rich relationship between inside and outside is build (fig.5-2).

\section{CONCLUSION: THE POSSIBILITIES FOR ARCHITECTS TO TRANSCEND FORM}

The common ground of the three houses is that they all have appositive public and private relationship resulting in a form which is the response to the public city environment as well as to the private interior behavior. The space forms of Atelier Bow-Wow's design come from a series of social researches instead of formal aesthetics. The design analysis above help us to understand the typical residential space strategy that Atelier Bow-Wow established from the theory of urban space and behavioral research:

1: Atelier Bow-Wow's attitude toward city is opposed to imitating urban form and fabric. Because of the chaos in Japanese cities, buildings have neither the opportunity nor the desire to pursue urban forms. Therefore, Bow-Wow uses a space-based dialogue with neighboring cities to establish the link between architecture and the city. The specific way of dialogue is based on the environmental reality around the project.

2: On the circumstances of chaotic city, Atelier Bow-Wow place great emphasis on the control of the architectural space by an interior living model. As Tsukamoto said "close the window is Japan, open the window is Tokyo." This "Japan" represents an inner way of life, and different ways of life are reflected in different internal spatial order.

This shows that the practice of Bow-Wow is a superposition of theory and reality. What is more worth mentioning is that its theory does not simply borrow the language in other disciplines, but lasts for a long time in space research and theoretical collation. As Stan Ellen said, architecture as a material practice is the practice of unity based on the process of its own development, rather than the theoretical reunification of the external ideological discourse obtained. This all confirms the positive significance of theory and practice in Atelier Bow-Wow's research and design especially in the chaotic East Asian city. 


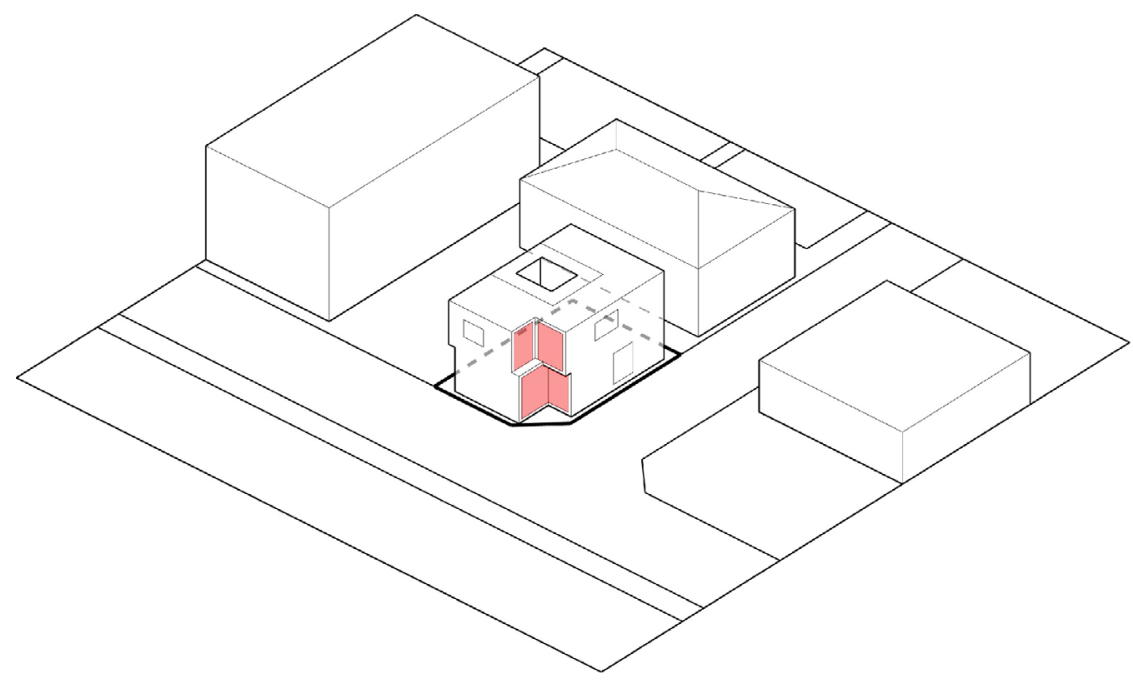

4-1: Site of Loco House

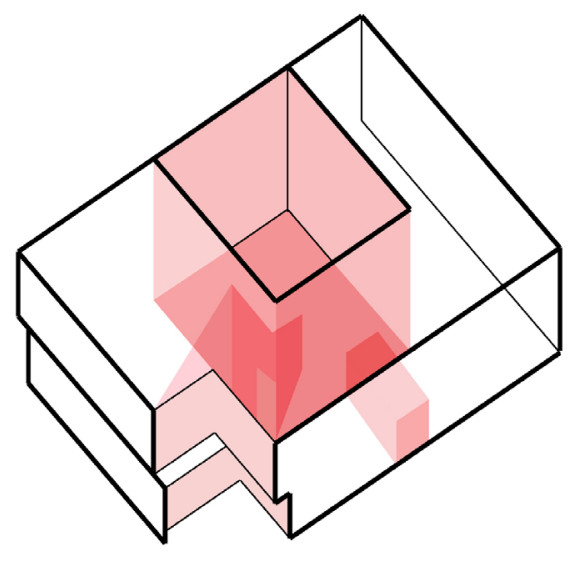

4-2: Share Space in Loco House

Fig.4 analysis of Loco House (drawn by the author)

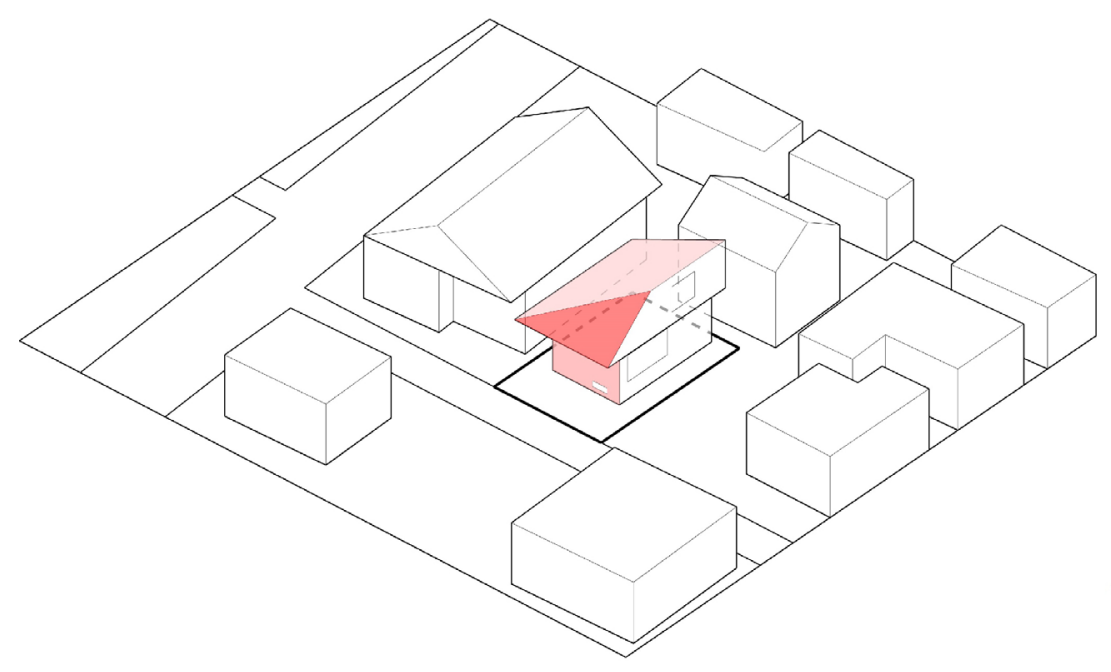

5-1: Site of Gae House

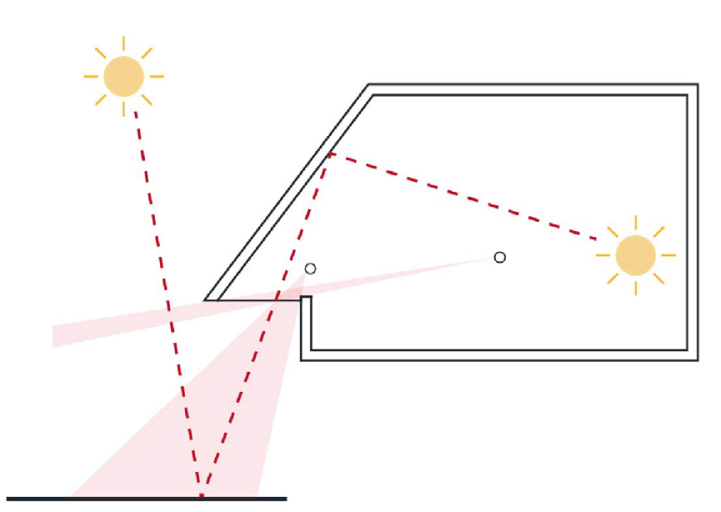

5-2: section of Gae house 
Through the theory and practice of Atelier Bow-Wow, we found that they rarely talked about the form alone, even intended to avoid the discussion of this topic. The modes of spatial operation of Atelier Bow-Wow are mostly from a series of social research including the urban environment and human behavior. This kind of social research and design strategy break through the limitation of formal aesthetic and solve the problems which cannot be solved by the discipline autonomy. Those social research make Atelier Bow-Wow out of the game of form and aesthetics and give them a different view of the city and society. The design method enriched by interdisciplinary studies allows the architects, Tsukamoto and Kaijima, to follow the flow of inspiration.

The urban environment and human behavior are only two of the social factors. We believe there are more aspects for further exploration. Thus, architectural form is no longer an empty shell without social meanings. Through these spatial operations, we can expand the boundary of architecture discipline and give today's architects more opportunities to transcend form.

\section{ENDNOTES}

This work is funded by NSFC (Grant No. 51778421)

Chen Qian is the corresponding author of this paper.

Bowwow, A. (2006). Bow-Wow from Post Bubble City. Tokyo: Inax.

Bowwow, A. (2007). Graphic Anatomy: Atelier Bow-Wow. (Tokyo: Toto.)

Stan Allen. Practice VS Project.[J].2008

6 Bowwow, A.(2006). House and Atelier Bow-Wow. JA, yearbook 2006, vol.64, (Tokyo: A+U Publishing Company), 67-77. 